\title{
Przechadzki
}

\section{Na pejzażu \\ (Poeta spotyka antropologa, i nie tylko jego)}

Zdzisław Łapiński

TEKSTY DRUGIE 2018, NR 2, S. 401-420

DOI: $10.18318 /$ td.2018.2.25

1

„Żyjąc - wdychałem aż do krwi krajobraz za krajobrazem, / gdziekolwiek spojrzę, pulsuje we mnie ich widok [...]". Tak pisał Julian Przyboś w roku 1939, w jednym ze swych najgłębiej filozoficzno-autobiograficznych wierszy (Żyjac, UP I 236 )'. Motywy krajobrazowe znajdujemy we wszystkich uprawianych przez niego gatunkach literackich. Nie tylko w lirykach, ale i w felietonach, esejach, „zapiskach bez daty”, prozie poetyckiej, „materiałach poetyckich" czy w scenariuszu poetyckiej etiudy filmowej (według jego własnego wiersza) ${ }^{2}$.

1 Skrótem UP oznaczam wydanie: J. Przyboś Utwory poetyckie, t. 1-2, oprac. R. Skręt, przedm. J. Kwiatkowski, Wydawnictwo Literackie, Kraków 1984-1994 (Pisma zebrane); cyfry rzymskie odsyłają do tomów, cyfry arabskie - do stron.

2 Także, oczywiście, w książkach historyków literatury jemu poświęconych (m.in. Edwarda Balcerzana, Andrzeja Cieńskiego, Krystyny Heskiej-Kwaśniewicz, Bogusława Kierca, Michaliny Kmiecik, Barbary Łozińskiej, Jerzego Kwiatkowskiego, Agnieszki Kwiatkowskiej, Małgorzaty Rygielskiej, Artura Sandauera, Barbary Sienkiewicz, Janusza

\author{
Zdzisław \\ Łapiński - prof., \\ członek kolegium \\ redakcyjnego \\ "Tekstów Drugich". \\ Zajmował się poezją \\ dwudziestowieczną \\ (Leśmian, Miłosz, \\ Białoszewski) oraz \\ Gombrowiczem. \\ Współredagował \\ Słownik realizmu \\ socjalistycznego \\ (2004). Ostatnio \\ opublikował wybór \\ wierszy Czesława \\ Miłosza w serii \\ Biblioteka Narodowa \\ (2013) oraz wydał \\ zbiór swoich prac \\ O Norwidzie (2014). \\ Autor kilkunastu \\ rozpraw i szkiców \\ o Przybosiu.
}


Dzianie się, czyli dzieje, to od strony poetyki Przybosia przede wszystkim procesy przyrody, a czas ma częściej wymiar dobowy niż historyczny: „Tu tylko się koło widnokręgu dzieje, na którym czas niebo skłonił" (Pola pochyte, UP I 103). Wprawdzie dzieje polityczne XX wieku ciągle zderzały poetę ze stającą się na jego oczach historią, ale w swych wierszach ujmował te fakty dziejowe za pomocą poetyki ukształtowanej przez światoodczucie biologiczne. Jego właściwą domeną była - aby posłużyć się określeniem Siergieja Eisensteina - „nieobojętna przyroda”.

Jeżeli krajobraz staje się zarówno przyczyną, jak i korelatem stanów wewnętrznych, to patrząc na niego, możemy dokonać samooglądu, czyli przejrzeć się w nim. Stąd takie słowa, jak te: „Zanim przejrzę się w rozstajnym krajobrazie" (Krajobraz, UP I 64).

Motywy współżycia z przyrodą, odczuwaną bezpośrednio, układają się w pewien wątek. Raz jest to świadome wyodrębnianie się ze swego środowiska naturalnego dobrze scalonego wewnętrznie „ja”, raz organiczny, ale agresywny stosunek podmiotu do otoczenia, kiedy indziej medytacyjne podporządkowanie się Naturze. Poeta dostrzegał w tych zmianach swego nastawienia pewien wyraźny kierunek: od agresji do akceptacji. Z dzisiejszej perspektywy można zauważyć, że przemiana jego postawy przebiegała równolegle do generalnego zwrotu w pojmowaniu epok geologicznych, bo to za jego życia helocen zaczął ustępować antropocenowi. Tak więc indywidualny czas ludzki zbiegł się tu z czasem planetarnym, biografia poety z biografią całego globu ${ }^{3}$.

Komponując swe wiersze, Przyboś miał w pamięci wielką tradycję naszej poezji krajobrazowej, od romantyków po Leśmiana. Korzystając z tej tradycji, wypracował własną oryginalną poetykę. Osiągnęła ona charakterystyczny dla siebie kształt, gdy autor (a) porzucił tradycyjne miary wierszowe i ustalił kontur nowego wiersza wolnego oraz gdy (b) skrystalizował podmiot wypowiedzi jako świadomość ucieleśnioną i osadzoną w konkretnym miejscu i czasie. Prototypem tego osadzenia było środowisko przyrodnicze, bo częste przecież w tych wierszach motywy urbanistyczne upodobniały się w percepcji do

Sławińskiego, Wiesława Pawła Szymańskiego, Justyny Tabaszewskiej, Danuty Zamącińskiej oraz $w$ trudnych do wyliczenia rozprawach innych autorów).

3 Krzyżującym się liniom indywidualnych życiorysów ludzi i życiorysów poszczególnych miejsc poświęcona została zbiorowa księga Landscape Biographies: Geographical, Historical and Archaeological Perspectives on the Production and Transmission of Landscapes, ed. by J. Kolen, H. Renes, R. Hermans, Amsterdam University Press, Amsterdam 2015. 
zjawisk naturalnych. Ponadto bohater liryczny wykazywał pewną aktywność fizyczną i bardzo intensywną aktywność psychiczną. Łączyło się to z przejściem od monologu do narracji, a raczej do mikronarracji, rozgrywającej się w krótkich odcinkach czasowych.

\section{2}

Przybosia zawsze pociągały i intrygowały sztuki wizualne:

Tak, tylko w malarstwie, tylko w patrzeniu malarskim doświadczamy bezpośrednio, widocznie, istoty widzialnej świata, czyli światła (i doczuwamy się innego, niewidzialnego). Jest ona znikliwie olśniewająca. $\left(\right.$ Iryda, ZBD 277) ${ }^{4}$

Korzystał zatem z każdej okazji, aby oglądać obrazy w muzeach, galeriach czy kościołach. Tę odmianę „świadomości wzrokowej”, którą odkrył i utrwalił na płótnie malarz, poeta wynosił w oczach z muzeum. Wpływała ona przez jakiś czas na bieżące postrzeganie krajobrazu dookolnego w sposób niemal fizjologiczny.

Bywało, że już zasypiając, miał przed oczami namalowany pejzaż (jak „[p] ejzaż Pissarra" w Zaokiennym neonie, UP I 173-174) - nawet jeśli to była tylko reprodukcja, zapewne licha. Podobnie wrażliwi na pejzaż byli jego najbliżsi: „Poślij / ... choć widokówkę, jak lek daleki na oczy!” - cytuje w wierszu zwróconą do siebie prośbę (Na widokówce, UP I 275).

Tak więc Przyboś swej sztuki krajobrazu uczył się nie tylko od pisarzy, lecz również od plastyków. Malarze bezpośredni kontakt z przyrodą nawiązują "na pejzażu”. Niezwykłe archiwum plenerowych szkiców znajduje się w Muzeum im. Wiktorii i Alberta w Londynie. Można tam podziwiać prawie trzysta prac Johna Constable'a, głównie są to studia olejne obłoków. W literaturze natomiast, uważał Przyboś, „[p]oeta nieba i obłoków jeszcze się nie urodził” (Obłoczność, UP II 70-71; cyt. 71). Pouczał jednak, jak doznawać obłoków: „Przesuń lewą, łagodniejsza dłonią po puszyście świetlistych okrajach, zapamiętaj obłok we wnętrzu dłoni, w dukli dotyku, uchwyć bardziej, uchwyć pozawzrokiem..." (Złoty obłok, UP I 365).

4 ZBD odsyła do: J. Przyboś Zapiski bez daty, PIW, Warszawa 1970. 
Prawdziwym męczennikiem pleneru była czołowa postać malarskiego modernizmu, Paul Cézanne. Dwudziestego października 1906 roku, Marie Cézanne, siostra artysty, pisała do jego syna, Paula:

Twój ojciec jest chory od poniedziałku... Przez wiele godzin był na deszczu, przywieziono go wózkiem z pralni; dwaj ludzie musieli go zanieść do łóżka. Nazajutrz wczesnym rankiem, poszedł do ogrodu malować portret Valliera pod lipą i wrócił umierający. ${ }^{5}$

Wprawdzie nie chodzi tu o krajobraz, lecz o portret, ale jednak portret plenerowy. Takie były koszty tego, aby po latach poeta mógł powiedzieć, że $\mathrm{z}$ "przeistoczonym wzrokiem wyszedłem ze zbiorowej wystawy Cézanne'a" (Przemienienie, ZBD 14).

Liryki Przybosia same są na swój sposób plenerowe. Autor pisze je tak, jakby powstawały podczas spacerów, i rejestruje, co się wówczas zdarzyło (choć opisuje to najczęściej w czasie przeszłym). Na przykład w wierszu Ciężar poematu szedł "lotny od pióra”, ale w pewnym momencie „niedokonany czas mojego - wiersza / stanąl” i przyszły autor musiał czekać, „aż się wzruszenie na tym stoku przyjmie, / aż wypełni rzeczywistość wezbraną -" (UP I 253). Niekiedy porównuje wynik własnej roboty z dziełem malarza: „Ze sztalugami przy żniwie / zbierasz widok tak dojrzały, że zaświeci / z płótna na powrót w słońce”. I kurtuazyjnie przyznaje, że „twój gotowy pejzaż” robi to „barwniej niż mój i wierniej" (Na pejzażu, UP I 272).

Poeta chciał podpatrzeć, jak radzą sobie malarze, przenosząc „motyw” na płótno. Chętnie zatem odwiedzał plastyków w ich pracowniach oraz wybierał się z nimi „na pejzaż". O tych wyprawach pisywał w esejach i wierszach.

\section{3}

Wśród krajobrazów przebywali zawsze etnografowie, archeolodzy i antropolodzy. Oni jednak ruszali nie „na pejzaż", ale „w teren” (in what they call 'the field', jak się wyraził jeden z nich ${ }^{6}$.

5 P. Cézanne Listy, zebrał, opracował, wstępem i komentarzem opatrzył J. Rewald, przekł. i przedm. J. Guze, PIW, Warszawa 1968, s. 293.

6 T. Ingold Clearing the Ground, w: tegoż Being Alive: Essays on Movement, Knowledge and Description, Routledge, London-New York 2011, s. 15). Na oznaczenie tej książki posługuję się dalej skrótem tytułu BA. 
„Ćwierć wieku temu książki z krajobrazem w tytule były właściwie nieobecne w antropologii", czytamy w Anthropology of Landscape Christophera Tilleya i Kate Cameron-Dunn? ${ }^{7}$ Od tego czasu antropolodzy, oraz tacy antropolodzy-archeolodzy jak Tilley, zaczęli odrabiać swe opóźnienie z tym większym zapałem. Czynili to tak skutecznie, że w końcu do samego pojęcia krajobrazu trzeba było wprowadzić korektę. Przeprowadził ją Tim Ingold, wysuwając alternatywę: „Landscape or weather-world?” (BA 126-135). On sam stanął po stronie „świata pogodowego”, jako że siłą ożywiającą środowisko, i nas w nim, jest atmosfera, czyli pogoda. A więc moglibyśmy powiedzieć, że chciałby się wybierać nie tyle „na pejzaż”, co „na plener".

Ingold tak sam siebie przedstawia we wstępie do Being Alive: „Antropologiem jestem. Nie antropologiem społecznym czy antropologiem kultury, nie przedstawicielem antropologii biologicznej czy archeologicznej, ale po prostu antropologiem" (BA XI) ${ }^{9}$. Zaraz jednak przyznaje, że nie można go uznać za typowego antropologa:

Sztuka, architektura i antropologia są sobie bliskie, bo wszystkie one obserwują, opisują i coś proponują. Istnieje być może dyscyplina akademicka, która czeka na zdefiniowanie i ochrzczenie. Tam spotykają się te trzy dziedziny. I jeśli znajdą się czytelnicy, którzy chcieliby uznać niniejszą książkę za rodzaj manifestu na rzecz owej dyscypliny, to nie będę zgłaszał sprzeciwu. (BA XI)

Autor dodaje jeszcze, wyliczając źródła swych pomysłów: „zaskoczyło mnie, jak wiele prac, które wywarły wpływ na moje myślenie, wyszło raczej spod pióra filozofów niż antropologów" (BA XI). Otrzymujemy zatem prawdziwy

7 C. Tilley, K. Cameron-Dunn Anthropology of Landscape: The Extraordinary in the Ordinary, University College London Press, London 2017, s. 1.

8 Ingold w swej uszczypliwej recenzji pisał o wcześniejszej książce Tilleya (The Materiality of Stone: Explorations in Landscape Phenomenology, Berg, Oxford 2004), że pełna jest, jak to nazwał, paradoksów. Chodziło mu o wewnętrzne sprzeczności, jakich się w niej dopatrzył. Ponadto bliski mu był wprawdzie „animizm” Tilleya, ale uznał, że autor jest w tym za mało radykalny. Brakowało mu w tamtej książce także opisu "medium” krajobrazów, czyli pogody. Tilley w swej przekonującej odpowiedzi przystał jedynie na ten ostatni zarzut. Zob. T. Ingold Lndscape Lives but Archeology Turns to Stones, "Norwegian Archeological Review" 2005 Vol. 38 No. 2, S. 122-126, oraz odpowiedź Christophera Tilleya Body Thoughts, tamże, s. 126-129.

Tu i dalej, o ile nie zaznaczono inaczej, cytaty w tłumaczeniu własnym. 
dyscyplinarny meshwork (ulubione słówko Ingolda), czyli, jak sam dookreśla, "a texture of interwoven threads" (BA XII).

W szkicu Landscape or Weather-World autor przedstawił „wyimaginowany scenariusz" spotkania Jamesa Gibsona z Mauricem Merleau-Pontym (BA 128-129). W literaturze przez długie wieki aktywny był gatunek zwany rozmową zmarłych. Była to fantazja polegająca na konfrontacji osób, które za życia nie miały okazji zetknąć się ze sobą. Na przykład Norwid dał taką szansę Byronowi i Rafaelowi (Rozmowa umartych. Byron, Rafael-Sanzio). Julian Przyboś (ur. 1901 - zm. 1970) nie żyje od blisko półwiecza, natomiast Tim Ingold (ur. 1948) wykazuje ciągle wielką żywotność. Chyba nie przeszkadza to jednak, by pozwolić im wejść w dialog. Nawiąże on do rozmów zmarłych, choć bez formalnych wskaźników tamtego gatunku.

Cytowany na początku mego szkicu wiersz ma tytuł Żjjąc. Można ten tytuł uznać za polski odpowiednik Ingolda Being Alive. Światoodczucie Ingolda to kolejna faza filozofii życia, zgoła dionizyjska, choć bez „maski Dionizosa”, bo jak pisał w 1961 roku Michał Głowiński: „Skarłowaciały Dionizos odszedł już na zawsze"10.

Życie przyrody według Ingolda objawia się najpełniej we fluktuacjach pogody. Wpływają one na całokształt naszego otoczenia, także na oporne z pozoru składniki, powiedzmy, kamienie. Jedną ze swych rozprawek (Materials against materialkity, BA 19-32) autor poprzedził i zakończył wskazówkami, jak mamy zorganizować scenę lektury jego tekstu. Otóż mamy wynaleźć kamyk, nie za duży i nie za mały, oblać go wodą, umieścić na biurku, na talerzyku (aby nie zmoczył nam laptopa) i podczas lektury zerkać na niego od czasu do czasu. A gdy skończymy czytać - zdradzam tu puentę - możemy go, osuszonego przynajmniej częściowo, jeszcze raz obejrzeć dokładniej, stuknąć lekko o ścianę itd. Uzmysłowimy sobie wówczas, jak zmienne są i zależne od czynników zewnętrznych jakości nawet tak samowsobnego przedmiotu jak kamień.

Jeśli chodzi o kamień, to chciałbym zwrócić uwagę na wstęp Ryszarda Nycza do poprzedniego numeru „Tekstów Drugich” (1/2018). Cytuje on Rozmowę z kamieniem Szymborskiej i rozwija ideę „zmysłu udziału”. Poetą, który miał u nas najsilniej rozwinięty ów zmysł, był Słowacki. W Pornic, gdzie objawiła mu się rzeczywistość w swej głębszej istocie, początek ewolucji Ducha dostrzegł w tamtejszych skałach: „W skałach więc już, o Panie, leży duch jako posąg doskonałej piękności, uśpiony jeszcze, ale już przygotowany na 
człowieczeństwo formy [...]"11. Dlatego mógł Słowacki użyć zaimka osobowego „ja” w sposób dość zaskakujący: „Podobnie jak to «ja» ptasie lub orne / Śpiące, a sobie jeszcze nieświadome"12.

Zwolenników posthumanizmu trzeba jednak przestrzec: Słowacki najwyższe, jak dotąd, wcielenie owego Ducha widział w „człowieczeństwie formy”, a w dodatku formę tę pojmował wcale nie somatycznie: „,wszystko przez Ducha i dla Ducha stworzone jest, a nic dla cielesnego celu nie istnieje"13.

Przyboś owej zasady nadającej ciągłość i jednorodność wszelkim przejawom istnienia szukał, oczywiście, nie w Duchu, lecz w trudnych do wysłowienia procesach psychosomatycznych. Dlatego też w klimacie intelektualnym jego twórczości dają się wyczuć echa nie tylko Słowackiego, ale i Nietzschego.

Natomiast Ingold do kamieni i skał odnosi się bez szczególnej sympatii, bo woli w ogóle unikać takich kategorii jak „przedmiot”, właśnie z racji, że wszystko ze wszystkim wchodzi u niego w „synergię”. Zaprawiając swoich studentów w sztuce patrzenia, Ingold zaprowadził ich kiedyś nad morze:

To, cośmy zobaczyli, to nie były przedmioty i powierzchnie, ale tworzywo w ruchu. Zapuszczając wzrok jeszcze dalej, dostrzegliśmy przyozdobione pianą fale, wzbierające jedna nad drugą. [...] Z tego tła mogliśmy jedynie mgliście wyodrębnić kołujące kształty ptaków morskich, ale rozpoznawaliśmy je nie jako przedmioty w ruchu, lecz jako sam ruch, któremu akompaniował niekiedy dźwięk. [...] Słowem, spoglądając na morze, zobaczyliśmy świat w ruchu, przelewający się i stawający, świat oceaniczny

11 J. Słowacki Genezis z Ducha, w: Krąg pism mistycznych, oprac. A. Kowalczykowa, wyd. 2, Zakład Narodowy im. Ossolińskich, Wrocław 1997 (Bibl. Nar. Seria I, nr 245), s. 17.

12 J. Słowacki Król-Duch, oprac. J. Krzyżanowski, w: tegoż Dzieła, red. J. Krzyżanowski, Wydawnictwo Zakładu Narodowego im. Ossolińskich, Wrocław 1949, s. 107. Na pewnej wystawie poświęconej Przybosiowi (w Muzeum Mickiewicza, prawie pół wieku temu), pokaźny głaz stanowił wraz z grą świateł oś wizualną scenerii. W druku okolicznościowym zestawiłem ze sobą bez komentarza szereg programowych wypowiedzi poetyckich Przybosia i Słowackiego. Zob. Sens poetycki. Julianowi Przybosiowi Muzeum Literatury im. Adama Mickiewicza, Muzeum Literatury im. Adama Mickiewicza, Warszawa 1973. Zainspirowała mnie rozprawa Danuty Zamącińskiej, „Widzę naprzód o wiek"?, w: Studia z teorii i historii poezji. Seria II, red. M. Głowiński, Zakład Narodowy im. Ossolińskich, Wydawnictwo PAN, Wrocław 1970, s. 265-278.

Wieloznaczny u Przybosia motyw kamienia ostatnio prześledziła, z intuicją poetki, Bogusława Latawiec. Zob. B. Latawiec Dzikie kamienie Juliana Przybosia, w: Przyboś dzisiaj, red. Z. Ożóg, J. Pasterski, M. Rabizo-Birek, Wydawnictwo Uniwersytetu Rzeszowskiego, Rzeszów 2017, s. 166-174.

13 J. Słowacki Genezis z Ducha, s. 45, drukiem rozstrzelonym. 
i niebny, świat pogodowy. Ujrzeliśmy świat bez przedmiotów (Landscape or weather-world, BA 131; kursywa autora).

Nie jest to świat obcy Przybosiowi. W lipcu 1977 roku, w miejscowości Kerhostin, w Bretanii, stojąc na plaży, starał się spojrzeć w oceaniczną dal oczami Słowackiego. Dostrzegł wówczas (i dosłyszał), jak „zgasły promyk zakwilił wysoko: / mewa" (Z rozłamu dwu mórz, UP I 147).

\section{4}

"Istota widzialnego świata, czyli światło", to w poezji Przybosia wprawdzie kategoria podstawowa, ale zawsze groziła odzmysłowieniem przedstawianej rzeczywistości. Pułapki tej nie ominęła większość jego późnych wierszy, w których chciał posłużyć się „narzędziem ze światła”. Bardziej produktywny okazał się inny składnik krajobrazu. Naprowadza na niego wiersz Do malarki (UP I 317-318). Poeta prosi w nim artystkę: „maluj / trafioną, farbującą pod pędzlem pogodę". Wezwanie skierowane jest do niej, ale jednocześnie mówi ono o jego własnych zamiarach pisarskich, bo malarka swym dziełem ma "przypominać", że i on ma „malować" pogodę. To przypomnienie brzmi zresztą retorycznie, bo już w tytułach wielu jego wcześniejszych wierszy widzimy przeróżne wskaźniki pogody, takie jak nazwy pór roku i pór dnia, stanów atmosfery itp.

O pogodzie jako zasadniczym dla siebie wątku pisze zresztą Przyboś wprost w Zapiskach bez daty. Zastanawia się tam:

A o czym pisze poeta? Co jest tematem jego poezji, co opisuje, o czym opowiada? Jakie to nadzwyczajne sprawy i rzeczy ujawnia, fantazjuje, wymyśla i nimi olśniewa? Jak jednym słowem moglibyśmy określić to, co pisze? (ZBD 126)

I odpowiada: „Pogoda. Poeta pisze o pogodzie”. Dalej zaś objaśnia:

Pogoda, powietrze, obłoki i słońce, deszcze, burze, roziskrzenie śniegów i zawieje, ocean powietrzny, w którym pływamy płucami - to one dają tchnienie, tchną tlenem, ciepłem i światłem - i o tym, o żywiole żywotności naszej, o nieustannej inspiracji, jest poezja. Uczuciowość nasza, wyobraźnia nasza, myśl nasza są wcieleniem stanów pogody w stany duchowe, duch jest na początku oddechem. 
Można by rzec, że doskonały poemat liryczny jest barografem pogody wewnętrznej poety. (ZBD 126)

Tak więc pogoda, „żywioł żywotności naszej”, przenika w głąb „stanów duchowych". Proces ten umyka jednak słowom. Aby go skonkretyzować, należy odwołać się do widzialnych stanów przyrody, które są tej pogody ekspresją. Dopiero wówczas można się własnymi odczuciami podzielić:

Uniósłszy ten krajobraz oprawiony w me ramiona zawieszę ci go na wietrze,

by ożył.

Przyjmij go, proszę.

(Widokówka, UP I 149)

Pogoda jako temat brzmi raczej sielankowo. Może warto więc przypomnieć, co miał do powiedzenia o niej pisarz, który wywarł przemożny wpływ na naszą kulturę przełomu stuleci, w tym także na światoodczucie samego Przybosia. Otóż według Fryderyka Nietzschego: „Aby mogła zaistnieć sztuka, aby mógł zaistnieć jakikolwiek czyn i ogląd estetyczny, nieodzowny jest warunek fizjologiczny: upojenie". Wśród odmian upojenia na pierwszym miejscu wymienia on „upojenie erotyczne, tę najstarszą i najpierwotniejszą formę upojenia”. Dalej następują: „upojenie świętem, rywalizacją, brawurowym dokonaniem, zwycięstwem, wszelkim ekstremalnym ruchem; upojenie okrucieństwem; upojenie niszczeniem”. A wreszcie „upojenie niektórymi zjawiskami meteorologicznymi, na przykład upojenie wiosną". W wierszach Przybosia wszystkie te „upojenia”, poza jednym, można od razu dostrzec. Nawet to najryzykowniejsze: „Wystarczy mi / zdrobniałemu w pokątnej mieścinie, / gdy / rzeź wielbię, / gdy zadymi bujna trawa na ruinie!" (Wiosna 1934, UP I 110). Obce mu tylko było „upojenie świętem”. Nie chciał się upajać ani religijnym, ani tym bardziej państwowym („Powietrze uduszono sztandarami", protestował w Równaniu serca, (1937), UP I 109). Chyba że byłoby to metaforyczne „święto wiosny”.

Dalej zaś pisze Nietzsche:

Istotą upojenia jest poczucie intensywności sił, poczucie pełni. Dzięki niemu człowiek użycza czegoś rzeczom, zmusza je, by odeń coś wzięły, gwałci je - proces ten nosi nazwę idealizowania. Musimy się uwolnić w tej 
kwestii od pewnego przesądu: idealizowanie nie polega, jak powszechnie sądzą ludzie, na pomijaniu czy odsiewaniu pomniejszych, ubocznych aspektów. Wręcz przeciwnie, zasadniczą rolę odgrywa w nim ogromne wydobywanie głównych rysów, dzięki czemu znikają pozostałe. ${ }^{14}$

Można dodać, że „idealizowanie” tutaj to tyle, co 'hiperbolizacja', a hiperbola, zdaniem innego patrona modernizmu, Charlesa Baudelaire'a, wynika z „przesadnego stanu żywotności” i jest w liryce formą językową „najbardziej konieczną"15. Warto zaś pamiętać, że Przyboś był w młodości projektodawcą efemerycznego Klubu Artystycznego „Dionizy” oraz autorem czterech wierszy opublikowanych w „Hiperboli”, jednodniówce tego klubu ${ }^{16}$. Skoro zaś mowa o intelektualnych patronach, to dorzućmy dla równowagi jeszcze jedno nazwisko, sugerujące zupełnie inne światoodczucie. W żartobliwym wierszyku Repetitorium Przyboś wspomina swe lata studenckie: „Tak, to ja na przechadzce od pojęcia - do drzewa / od Spinozy - do brzozy" (UP I 306). W wersji brulionowej sens tego fragmentu był dobitniejszy: „park Jordana” „odwodził od Spinozy do brzozy poezji" (UP I 632). Czy jednak były to naprawdę tak przeciwstawne przeżycia?

\section{5}

Obok motywu pogody jednym z wyróżników twórczości Przybosia jest motyw linii. Linie, wektory czy „napięcia kierunkowe” zawsze go pobudzały, nie tylko dlatego, że „[l]inią powietrzną najbliżej / ze wspomnienia wrócić [...]” (Linia powietrzna, UP I 264).

Poeta własne doznania sensualne jako wieloletniego mieszkańca Śląska Cieszyńskiego przedstawił w prozatorskiej etiudzie Linia i gwar. Rzecz włączył następnie do powojennego zbioru szkiców, a jej tytułem opatrzył dwutomową całość. (Swoje trzy grosze mogłaby wtrącić Maria Konopnicka, autorka zbiorku poetyckiego Linie i dźwięhi z 1897 roku, jednak nie dopuszczam jej do głosu, bo puenta całego zbiorku, wierszyk Dźwiękjedyny..., zbyt kłóci się

14 Wszystkie cytaty z Nietzschego w obu akapitach: F. Nietzsche Zmierzch bożyszcz czyli jak się filozofuje młotem, przeł. i wstępem opatrzył G. Sowiński, Wydawnictwo „A", Kraków 2000, s. 78. Ch. Baudelaire Sztuka romantyczna. Dzienniki poufne, przeł., wstępem i przypisami opatrzył A. Kijowski, Czytelnik, Warszawa 1971, s. 207.

16 Zob. J. Duk Kalendarium życia i twórczości Juliana Przybosia, w: Wspomnienia o/ulianie Przybosiu, oprac. i wstęp J. Sławiński, Ludowa Spółdzielnia Wydawnicza, Warszawa 1976, s. 451-453. 
z wrażliwością Przybosia: „Linia, w którą życie łamie / Wszystko, co ma ducha znamię, / To mogilny krzyż!").

W szkicu Rzeźba napowietrzna (SP I 305-310) ${ }^{17}$ Przyboś opowiada o swej wizycie na plenerze malarskim w Osieku, gdzie artyści, z braku odpowiedniego lokalu, rozstawiali lub rozwieszali swe gotowe prace na świeżym powietrzu. Poeta doradzał im (półserio), aby tworząc, zakładali od razu ową nietypową formę ekspozycji i zapoczątkowali „nowy kierunek w sztuce: «aeryzm»”. W chwilę później trafił na takie właśnie dzieło, nie malarskie zresztą, lecz rzeźbiarskie:

Kompozycja Krasińskiego zawieszona była w powietrzu; unosiła się cudem jakiejś lewitacji - z trawy, w której zostawiła swoje czerwone rozpryski, początkowo pionowo w górę, nabierała, skręciwszy nagle w poziom, siły uwyraźnionej smuklejącą, z czerni w biel biegnącą długością, po czym przerwawszy swoją ciągłość - narzucała się po przerwie (pełnej oczekiwania ciosu) ostrym, coraz czerwieńszym końcem kłującym horyzont. Ȧz wykrzyknąłem - zdumiony: oto dzieło ,aeryczne”, rzecz nowa. Zbliżywszy się, pojąłem cud lewitacji: Krasiński rozpiął swoją „dzidę epoki atomowej" (tak ją sobie nazwałem) na cienkich drutach od drzewa do drzewa. Ale drutów się nie widziało, pędząca dzida miała w oczach oglądającego swoje własne pole grawitacyjne... (SP I 305-306)

Przyboś w tym i w następnych artefaktach Krasińskiego dostrzegał końcową fazę wyzwalania się rzeźby z determinujących ją dawniej nakazów, proces zapoczątkowany u nas przez Katarzynę Kobro.

Rzeźba była zawsze czymś wyosobnionym z trójwymiaru, objętość rzeźby przeciwstawiała się dookolnej przestrzeni. Na przeciwstawieniu i grze tych dwu obszarów (objętości bryły i dookolnej przestrzeni) zasadzało się oddziaływanie plastyczne rzeźby. [...] Katarzyna Kobro zburzyła pojęcie rzeźby jako bryły. Jej rzeźby są czymś zasadniczo innym niż skulptura tradycyjna. Rzeźbiła nie jakikolwiek materiał, marmur, glinę, gips, żelazo, drewno lub tym podobne, ale samą przestrzeń: kształtowała więc tę próżnię, tę głębokość, nie wypełnioną żadnym materiałem, która nas otacza. (SP I 307)

17 Skrótem SP oznaczam wydanie: J. Przyboś Sens poetycki, wyd. 2, t. 1-2, Wydawnictwo Literackie, Kraków 1967; cyfry rzymskie odsyłają do tomów, cyfry arabskie - do stron. 
Tak więc „Katarzyna Kobro otworzyła więzienie bryły rzeźbiarskiej, wyzwoliła w plastyce przestrzeń". Ale

[j]ej kompozycje formułujące próżnię oparte były na założeniu, że przestrzeń jest ciągła. Zakładały nieskończone continuum. Płaszczyzny zaznaczające podział przestrzeni złączone były ze sobą. Obserwator o tradycyjnym zmyśle rzeźbiarskim mógłby je wziąć za cel sam w sobie, a nie za, niestety, nieunikniony środek do celu: do kształtowania przestrzeni. (SP I 308$)$

Edward Krasiński poszedł o krok dalej:

Dzidy Krasińskiego posiadają określoną grubość, można by je więc traktować jako bryły rzeźbiarskie, zwłaszcza, że ta ich grubość jest zmienna, że cienieją na końcu jakby ostrze w szpic, w punkt. Ale ich polichromia - Krasiński używa tylko jednego koloru jako znaku ruchu: czerwieni oraz bieli-czerni dla oznaczenia „poślizgu” ku ostatecznemu pędowi zaznaczonemu coraz intensywniejszą czerwienią - ale ta ich polichromia sprawia, że nie utrwalają się w oczach jako objętości, jako masa wydłużonej okrągło bryły. Widzimy nie drzewca, nie dzidy, nie ostrza, ale coraz spieszniejsze linie wystrzelone w przestrzeń. Krasiński sprowadził rzeźbę d o li nii. (SP I 308; druk rozstrzelony w podstawie)

Dla Przybosia malarstwo było pod pewnym względem sztuką bardziej odkrywczą niż poezja („plastycy wcześniej zazwyczaj przeczuwają nowe formy życia niż pisarze", Obelisk i ruch, LIG II $252^{18}$ ). W poglądzie tym nie był odosobniony. Ale znacznie wcześniej niż inni pisarze, a nawet historycy sztuki przeczuł, że w drugiej połowie tamtego stulecia siłą napędową w rozwoju sztuk wizualnych zacznie się stawać rzeźba, nie zaś malarstwo. Zrozumiał barierę na jaką trafili malarscy abstrakcjoniści. Na arenie międzynarodowej donośnie zabrzmiał w tej kwestii dopiero głos Rosalindy Krauss, która dla niejednorodnych nowszych kierunków dostrzegła wspólny mianownik właśnie w tradycji rzeźbiarskiej (artykuł Sculpture in the expanded field, 1978).

Świat w ruchu, świat odprzedmiotowiony, a raczej świat jako grę wektorów poeta wyrażał głównie w swych poetyckich studiach krajobrazu

18 Skrótem LIG oznaczam wydanie: J. Przyboś Linia i gwar. Szkice, t. 1-2, Wydawnictwo Literackie, Kraków 1959; cyfry rzymskie odsyłają do tomów, cyfry arabskie - do stron. 
(pogodowego). Chciałbym jednak posłużyć się przykładem krajobrazu czysto miejskiego. Przyboś tak pisze o swych wrażeniach, gdy stał w Paryżu w 1937 roku „pod ogrodem Tuilleryj” i spoglądał "na wirujący autami Plac Zgody”:

Wpatrzony w całość ruchliwej przestrzeni, nie liczyłem wozów, nie analizowałem wrażenia. $Z$ całości placu pozostała mi wizja dwu poziomych półkolistych ruchów, okrążających pion obelisku. Jakby ktoś olbrzymi, stojący po drugiej stronie Sekwany na szczycie Izby Deputowanych, ustawicznie zarzucał śmigłe lasso na stojący w środku placu obelisk i jakby to niedomknięte w rzucie lasso wciąż pękało, skiełznąwszy po słupie.

Wzrok ustawiony na wysokości obeliskowego szczytu znosiłem szybko w dół na poziom ruchliwego placu i przepełniony pędem równie szybko podnosiłem go w górę. Krzyżowały się w widzeniu linie, rozstrzeliwały się i skupiały w wizję przeciwstawnych obrazów. Zespalały się sprzeczne kierunki. spadał pion i rozpłaszczał się w wirujący poziom, i wirujące półkola zwężały się w miarę, jak oko biegło i nieruchomiało u szczytu obelisku. Tak narzucał się trójwymiarowy obraz Placu, ustawicznie się w sobie zwierającego - i rozpraszającego: Rozstrzał i gwałtowne skupienie, cios za ciosem wymiarów, odpychanie się i wnikanie w siebie kierunków. (Obelisk i ruch, LIG II 249-250)

W to miejsce poeta wracał wielokrotnie:

Zawsze doznawałem wzruszenia nieporównywalnego z żadnym innym. Nie wątpiłem jednak, jakiego rodzaju to wzruszenie: estetyczne. Radowała mnie nie architektura, nie urbanistyczne rozplanowanie Placu. Te ramy ginęły w moim widzeniu, oczy porywał sam obraz: ruch; bo on był treścią formującą otoczenie, on dopiero ujawniał istotę przestrzenną placu. Niewidzialna tkanina napięć rytmicznych między wirującym poziomem i nieruchomym pionem obelisku stwarzała coś, czego jeszcze nikt w przeżyciu plastycznym nie określił. (Obelisk i ruch, LIG II 250)

Przyboś nie mógł wiedzieć, że - wówczas, gdy patrzył, i wówczas, gdy wracał tam wspomnieniem - nie tylko wyobrażał sobie jakiś niebywały artefakt sztuk plastycznych, ale artefakt taki na naszych oczach tworzył. Wiersz na podobny temat, Cztery strony (1937) (UP I 137), pozostawał utworem, w każdym sensie tego słowa, poetyckim. Natomiast przytoczony zapis-projekt 
z dzisiejszej perspektywy, po zadomowieniu się w naszej kulturze wizualnej wytworów sztuki konceptualnej, należy uznać za gotowe dzieło plastyczne, konceptualne.

\section{6}

Przyboś, który zmarł w roku 1970, nie mógł śledzić kolejnych przemian, jakim Edward Krasiński (3 marca 1925 - 6 kwietnia 2004) poddawał swoją materię twórczą. Rzeźbiarz zaczął się wycofywać ze swoich wypraw w dal, a jego uwagę przykuwało coraz częściej najbliższe otoczenie. Posługiwał się niebieskim paskiem, który naklejał w sposób ciagły na ścianach, podłogach, meblach i innych przedmiotach - pogodna ścieżka wyznaczająca bieg wzroku po zamkniętej przestrzeni własnego warsztatu lub sal wystawienniczych ${ }^{19}$.

Jeśli Krasiński „sprowadził rzeźbę do linii”, to Ingold do linii sprowadził znacznie więcej. Jego Lines: A Brief History zaczynają się od pytania: „Co mają ze sobą wspólnego przechadzanie się, tkanie, przyglądanie się, śpiewanie, rysowanie i pisanie?". Zaraz też otrzymujemy odpowiedź: „Wszystkie te czynności biegną wzdłuż jakichś linii. W niniejszej książce zamierzam stworzyć podwaliny pod coś, co można nazwać antropologią porównawczą linii. O ile wiem, niczego podobnego nie podejmowano dotąd"20.

Linie Ingolda, podobnie jak linie Przybosia, biegną w przestrzeni wyobrażonej, taśma Krasińskiego jest całkiem namacalna. Rzeźbiarz zapewne chętnie naniósłby swą taśmę na coś takiego jak różne procesy wymienione (i niewymienione) przez Ingolda. Skoro było to niemożliwe, poprzestał na rzeczach dostępnych.

\section{7}

Wracając do sposobów przebywania w świecie. Dla Ingolda najwłaściwszy sposób to wędrowanie. Podobnie dla Przybosia. Skromny bohater wiersza O przechodniu (UP I 242) „stawia kroki niewielkie, tak wyrabia sobie drogę

19 Jego wystawy odbywały się w Wielkiej Brytanii, były dobrze przyjęte, i może brytyjski antropolog je widział. Jednak w publikacjach Ingolda nie trafiłem na żadną wzmiankę o tym. Zgaduję tylko, że konceptualizacje Krasińskiego przypadłyby mu do gustu. A tu służą mi one jako obrazowe tło dla percepcyjnych zainteresowań obu bohaterów artykułu.

20 T. Ingold Lines: A Brief History, Routledge, London-New York 2007, s. 1. Autor nie ukrywa jednak źródeł swych koncepcji, źródeł zarówno rodzimych, jak i franko-germańskich (Bergson, Heidegger, Merleau-Ponty, Deleuze, Guattari...). 
uboczną...”. Autor tych słów chodził inaczej. Stanisław Grochowiak napisał, że Przyboś „[s]zedł tak pięknie, jak tworzył”, i przytoczył uwagę swego przyjaciela: „To było tak, jakby się powstrzymywał, jakby walczył z niepohamowaną chęcią ruszenia biegiem... Bo On idąc biegł; biegł z dziecięcą zachłannością naprzeciw całemu widzialnemu światu"21. Myślę, że do idącego Przybosia pasowałyby też słowa Norwida: „Młody i całym sobą wyprzedzony”22. On sam przedstawił taki autokomentarz:

Nie wysiaduję wierszy, ale je wychadzam, jak serce utleniam w wolnej przestrzeni, na spacerze wśród pól, w lesie, w parku.

Układając tak - perypatetycznie - wiersze, sprawdzam ich rytm i dźwięk w oddechu, poruszeniach ciała, w rytmie kroków, w zatrzymaniach się, przyśpieszeniach, zwolnieniach chodu. A nade wszystko w tym, co trudne jest do określenia, a co chyba najogólniej, a więc niedokładnie, można by nazwać - porozumieniem ze światem zewnętrznym. (Stowo ibyt, ZBD 177-178)

Także dla Ingolda przyrodzony ludziom sposób istnienia w świecie to wędrowanie (wayfaring). Przeciwstawia je „przemieszczaniu się” (transport), podczas którego punkty docelowe usuwają z pola doświadczeń sam przebieg czynności. Lojalnie muszę jednak przyznać, że ostentacyjnie wyprostowana postawa Przybosia spotkałaby się z krytyczna oceną Ingolda, bo symbolizowałaby ona nowożytne wywyższanie się człowieka. Tadeusz Różewicz z niepokojem obserwował kiedyś swego synka, kiedy ten próbował stanąć na nogach, a potem westchnął z ulgą: „znów się udała ta stara sztuczka ludzkości"23. Tymczasem Ingold, podejrzewam, nie miałby nic przeciwko naszym wędrówkom na czworakach.

Kazimierz Wyka przypominał, że „przyboś” to przysłówek, oznaczający chodzenie wprawdzie w butach, lecz na gołą stopę ${ }^{24}$. Dla Ingolda chodzenie przyboś to za mało. Wygłosił całą diatrybę przeciwko wynalazkowi obuwia

21 S. Grochowiak Pan Julian, w: Wspomnienia o Julianie Przybosiu, s. 431.

22 C. Norwid Wędrowny sztukmistrz, w: tegoż Poematy, t. 1, oprac. S. Sawicki, A. Cedro, Towarzystwo Naukowe Katolickiego Uniwersytetu Lubelskiego Jana Pawła II, Biblioteka Narodowa, Warszawa-Lublin 2009 (Dzieła wszystkie, t. 3), s. 95. lińskich, Wrocław 1971, s. 311. 
jako zapowiedzi zwrotu od idei „wędrowania” do „przemieszczania się”. A cytując Clifforda Geertza, który oznajmił, iż człowiek ,jest stworzeniem zawieszonym w sieci znaczeń, które sam utkal”, z przekąsem dodal, że „tylko obuty i ukrzesłowiony człowiek, czy to w ruchu, czy w spoczynku, zawsze sztucznie oderwany od bezpośredniego kontaktu z gruntem - mógłby uważać się za zawieszonego w ten sposób" (Culture on the ground: the world perceived through the feet, BA 39).

Uznaję to wprawdzie za poetycką hiperbolę, lecz kryją się za nią istotne różnice między Przybosiem a Ingoldem. Pomijam oczywistą rozbieżność w rozumieniu postępu. Przyboś był wyznawcą „światopoglądu ściśle poetyckiego" (Światopogląd ściśle poetycki, ZBD 289-294), mimo to odnosił się z respektem nie tylko do filologii akademickiej, ale i do nauk ścisłych. Z tak wielkim respektem, że chętnie wprowadzał do swych wierszy terminy techniczne ${ }^{25}$. Niekiedy zresztą próba godzenia dwu tak różnych postaw w jednym utworze lirycznym kończyła się artystycznym niepowodzeniem. Ingold w swojej prozie unikał terminów technicznych i przyjętych w jego dyscyplinie form argumentacji oraz w ogóle był zdecydowanym przeciwnikiem wszelkich „scjentyzmów”. Z drugiej strony, bliższe przyjrzenie się obu pisarzom pozwoliłoby dostrzec u każdego z nich splot sprzecznych intencji i podważyło jednoznaczność postaw.

\section{8}

Zajmując się Ingoldem, nie można nie wspomnieć o jego słuchu literackim. Meshwork Ingolda jest nie tylko wyrafinowany metodologicznie, ale i świetnie napisany, a raczej - by użyć bliskiego autorowi aspektu niedokonanego - pisany. Jego szkice znajdują się w pół drogi między prozą poetycką a rygorystyczną prozą akademicką. Roman Ingarden wyraził się o prozie naukowej (jako gatunku wypowiedzi), że jej sensualność jest „skarłowaciała”. Proza Tima Ingolda na tę dolegliwość nie cierpi, wynika ona z impulsu bliskiego artystom. Podtytuł mego szkicu mógłby równie dobrze brzmieć: „poeta spotyka poetę". Antropolog ten to „sztukmistrz", w sensie Norwidowskim².

25 Np. w wierszu Daleka, co noc bliższa taki termin występował już w autografie i pierwodruku: „Dziś mój sen jak chrom wywołał cię z nocy” (UPI 599), ale później autor swe określenie skorygował: "Mój sen, jak z bromku srebra, wywołał cię z nocy” (UP I 245). 
Przykładem może być użytek, jaki autor robi z przyimka. Przyimek to skromna część mowy, znaczeniowo niesamodzielna, choć miała ona kiedyś swój moment w dziejach myśli europejskiej. Jak wieść niesie, przyimek przyczynił się do ustanowienia obecnego (bardzo zresztą ogólnego) znaczenia "metafizyki". Fakt ten uznał nawet za godny odnotowania Martin Heidegger, w nocie wstępnej do przygotowanych po latach do druku wykładach z roku 1928, Metaphysische Anfangsgründe der Logik im Ausgang von Leibniz. „Biblioteczna", jak ją nazwał, geneza pojęcia "metafizyka” to wynik niewłaściwej interpretacji greckiego przyimka "meta”. Przyimek ten wskazywał pierwotnie na czysto kompozycyjne miejsce ksiąg poświęconych ontologii i teologii, tj. za traktatem dotyczącym „fizyki”. W dalszej recepcji dotychczasowy sens przyimka meta ('za') został odczytany jako 'poza'. Odtąd „metafizyka” miała wskazywać na coś poza czy ponad wszelkimi rodzajami bytów (objętych wspólną nazwą „fizyka”).

Można powiedzieć, zachowując wszelkie proporcje, że i u Ingolda komentarz do form przyimkowych oraz to, jak on sam się nimi posługuje (często w sposób wysoce niekonwencjonalny) - także nie są pozbawione ambicji filozoficznych.

Przyimki są ważne dla Ingolda, bo stanowią gramatyczne narzędzie dla wyrażania przestrzennych wymiarów i kierunków. To one pozwalają skrajnie syntetycznym w wymowie liniom nadawać pewną wyobrażeniową konkretność. Jeden z rozdziałów Lines zatytułowany został $U$, across and along (L 72-103). Przyimki te, wraz z innymi, wykorzystał autor, by unaocznić dwa różne pojęcia ludzkiego ruchu, owe "przemieszczania się" $\mathrm{i}$ „wędrowania”.

W pewuenowskiej Kulturze języka polskiego (Warszawa 2006) znajdujemy następującą poradę dotyczącą niektórych zwrotów przyimkowych: „Akceptowane są przede wszystkim takie użycia, w których przyimek zapowiada relacje przestrzenne" (s. 216). Otóż wynalazczość stylistyczna polega właśnie na nieoczekiwanym a celowym przenoszeniu kategorii przestrzennych w bardziej abstrakcyjne rejony.

Podobne zabiegi można przeprowadzać także w sztukach wizualnych. Tam jednak metaforyczny chwyt polega nie na ujmowaniu zjawisk pozapercepcyjnych w kategoriach przestrzennych, ale na robieniu jakby wyciagu z różnorodnych pojedynczych spostrzeżeń konkretnych i przedstawianiu tego

Improvisation, zorganizowanej w roku 2005 w Aberdeen przez Assotiation of Social Anthropologists (zob. Seven variation on the letter A, BA, 181-195) 
wyciagu w sposób naoczny. Komentarza dostarcza Przyboś oglądający Obraz lasu Strzemińskiego:

Widzenie Strzemińskiego odpowiada uderzająco mojemu syntetycznemu widzeniu kształtów. Ileż lasów widziałem i z dołu, i z góry - z samolotu - i oto owe lasy przyszły do mnie w tym rysunku lekkim, powietrznym, a obliczonym i precyzyjnym - wszystkie. Linia wznosząca się z prawej strony daje potężniejsze wrażenie olbrzymiego drzewa niż najpotężniejszy dąb widziany w rzeczywistości. Strzemiński - to z e ś r o d k o w a n i e (koncentracja) widzenia. (ZBD 89-90; druk rozstrzelony w podstawie)

Upodobanie Przybosia do przyimków było nie mniejsze niż Ingolda. Śledził, jak posługują się nimi jego poetyccy mistrzowie. W uwagach o Mickiewiczowskim "Szczęścia w domu nie znalazł, bo go nie było w ojczyźnie” (z Konrada Wallenroda) wskazał m.in. na implikowany przez to abstrakcyjne zdanie obrazowy zarys przestrzenny - wizerunek czegoś mniejszego zawartego w czymś większym²7. (W gramatyce kognitywnej jest to dobrze znany schemat obrazowy).

Przede wszystkim jednak Przyboś z wirtuozerią posługiwał się wyrażeniami przyimkowymi we własnych wierszach. Umieszczał je nie tylko w tytułach poszczególnych utworów, jak w Z zakrętu, z drogi nagłej (UP I 115) czy Z podróży (UP I 141), ale i w tytułach książkowych. Za istny manifest przyimkowy można uznać tytuł pierwszego tomiku, w którym autor ustalił zrąb swej indywidualnej poetyki: Sponad. Tutaj ta niesamodzielna cząstka mowy uzyskała autonomię i znalazła się na honorowym tekstologicznie miejscu, a ówczesna ortografia („z ponad”) jeszcze udobitniała brzmienie. Wprawdzie oryginalny układ typograficzny Władysława Strzemińskiego przesłonił foniczną stronę tytułu, jednak w publicznej recepcji tego tomu, czyli w omówieniach prasowych, potencjalne brzmienie występowało zgodnie z intencją poety.

Ponieważ mowa wiązana ma w swym repertuarze środki niedostępne prozie, Przyboś sięgnął po jeszcze jeden sposób uwydatnienia przyimka i nadawania mu nowej siły znaczeniotwórczej. Był to sposób, o którym Ingold mógł tylko marzyć. W wierszu Nike (UP I, 188) czytamy: „Biciem serca, cios za ciosem, uderzałem w...”. W późniejszym komentarzu autor objaśniał:

27 J. Przyboś Humor i prostota (Odpowiedź Wacławowi Borowemu), w: tegoż Czytając Mickiewicza, wyd. 4, Oficyna Wydawnicza Rytm, Warszawa 1998, s. 258-262. 
Urwałem na przyimku, zamilkłem w miejscu, w jakim jeszcze nikt nie odważył się na zamilknięcie [...]. I dorzucił: „naśladowcy zrobili z takiego urwania wersu na przyimku konwencję mechanicznie praktykowaną, nigdy prawie nie umotywowaną koniecznością, rzadko więc służącą treści. (Drobiazg, ZBD 183-184)

\section{9}

Ten stopień zaangażowania w najdrobniejszy szczegół własnego warsztatu, jaki widzimy u Ingolda i Przybosia, byłby niemożliwy bez wiary w misję uprawianych przez nich dyscyplin. Przyboś wyraził się wprost. Dla niego poeta jest „człowiekiem najbardziej kulturalnym, najbardziej wśród ludzi ludzkim, czyli artystą", a jego prawdziwie odkrywcze wiersze to akty „, autokreacji człowieka" (Oko dziewicze, ZBD 180).

Ingold potraktował rzecz mniej osobiście. W wywiadzie udzielonym jednemu z czasopism antropologicznych zaznaczył różnicę między antropologią a etnografią. Etnografię określił jako „z gruntu opisową, czyli dokumentalną". Antropologia natomiast, jego zdaniem, zawiera „bardzo ważny składnik spekulatywny”, „ma ona myśleć nie o tym po prostu, jak życie jest czy było przeżywane przez tę lub inną grupę ludzi, lecz jaki w ogóle potencjał zawiera życie”. Dlatego sądzi, że „zadania antropologii powinny być transformatorskie”, ma być ona „nastawiona na przyszłość". I dodaje: „taka jest według mnie misja antropologii"28.

Doprawdy, godna szacunku i namysłu wiara ${ }^{29}$.

28 Wszystkie cytaty w tym akapicie: L.F.A. Ferrándes Ways of Living: Tim Ingold on culture, biology and the anthropological task, "AIBR. Revista de Anthropologia Iberoamericana” 2013 Vol. 8 No. 3, s. 285-302.

Moje spojrzenie na Ingolda jest spojrzeniem krytyka literackiego. Stronę uczoną jego twórczości antropologicznej opisuje cierpliwie Katarzyna Wala, etnografka niezrażona chłodnym stosunkiem Ingolda do etnografii. Zob. jej Ułożyć świat na nowo. Rekonstrukcja koncepcji Tima Ingolda, "Etnografia. Praktyki, Teorie, Doświadczenie” 2016, t. 2, s. 189-209. Czasopismo „powstało z myślą o rozpowszechnianiu tekstów na temat doświadczeń terenowych", a rozprawka Wali to pierwsza część zamierzonego na trzy odcinki sprawozdania. Autorka, razem z Magdaleną Zych, przeprowadziła też w grudniu 2013 roku wywiad z Ingoldem, który włączył tę rozmowę (pt. Letters from Cracow) do swojej książeczki Correspondences: Knowing from the Inside, University of Aberdeen, Aberdeen 2017, s. 122-138. Polska wersja pt. Ruch, którym jesteśmy, zawiera też ruch naszych myśli ukazała się w "Autoportrecie” 2014 nr 2, s. 11-15. 


\section{Abstract}

\section{Zdzisław Łapiński}

THE INSTITUTE OF LITERARY RESEARCH OF THE POLISH ACADEMY OF SCIENCES (WARSAW)

Into the Landscape: A Poet Meets an Anthropologist

Łapiński offers a few comparative remarks on the Polish avant-garde poet Julian Przyboś (1901-1970) and the British social anthropologist Tim Ingold (born 1948). The analysis touches on various issues from stylistic features such as their use of prepositions to their processual ontologies.

\section{Keywords}

nature, landscape, weather, perception, senses, being alive 